\title{
Literature For Media Tourism Promotion (Review Semiotics)
}

\author{
Fifi Nofiyanti ${ }^{1}$, Filma Festivalia ${ }^{2}$ and Mimi Enggriani ${ }^{3}$ \\ ${ }^{1,2,3}$ Sekolah Tinggi Pariwisata Trisakti, Jakarta, Indonesia \\ Email: ${ }^{1}$ fifi.nofiyanti04@gmail.com, ${ }^{2}$ FFFestivalia_06@yahoo.co.id and ${ }^{3}$ mimienggriani@gmail.com
}

\begin{abstract}
This study aims to explore the literary works such as novels which have tourism background. Literary works and tourism can be attributed to a close. The existence of two functions that can be implemented, namely the promotion of tourism and increase the reading habit. There are seven novels that were examined in this study, taking publication year 2000 to 2017. The research method used is descriptive qualitative study of semiotics. $80 \%$ novel tells about the natural beauty and attractions with a different theme is love, friendship, religion, culture, customs, and social life. Seven novels studied contains background are: Sindoro, Islamic civilization in Europe, Belitung, Yogyakarta, NTT, Mount Mahameru, and Bali. Some of the novel has been made into a movie. The results of this study showed that this novel form of literature can be used as a promotion tour. Based on the data obtained that there are some attractions that increase visitors, after rising and the screening of some of the novel. By reading the novel, the reader is invited to imagine to the area depicted in the background of the story. It became part of the way of promotion. Clearly illustrated in the Laskar Pelangi (Rainbow Troops) written by Andrea Hirata, later made into a film. Until the emergence of Andrea Hirata museum become a new tourist attraction in the Pacific Islands. Readers are invited imagination to the area depicted in the background of the story. It became part of the way of promotion. Clearly illustrated in the Laskar Pelangi novel written by Andrea Hirata, later made into a film. Until the emergence of Andrea Hirata museum become a new tourist attraction in the Pacific Islands. Of the seven novels analyzed, according to the classification of the more dominant tourism types tell about agro tourism or natural beauty.
\end{abstract}

Keywords: Literature, Novel, Promotion, Tourism

\section{INTRODUCTION}

Tourism in Indonesia has become the main purpose of the public to visit during the holidays. In contrast to previous years, tourism is not too ogled by the public. This is certainly due to the influence of the media campaign that is growing and sophisticated. According to the law no. 10 of 2009 on tourism, tourism is a tourist activity that is supported by the services and facilities provided by the government, employers, and society. Area known tourism destinations, will increase the income of the area and surrounding communities, as well as reducing the number of unemployed. The need for various levels of society to jointly build a tourism promotion, for the achievement of common goals. The digital age today is promoting cyber-promotion, but do not forget about the various aspects of the media campaign that is displayed to introduce the Indonesian tourist destinations.

According to Ismayanti (2010: 82), the types of tours are divided into 7, namely: sports tourism, culinary tourism, religious tourism, agro tourism, cave tours, ecological tours, and shopping.

Based on the research of Priyatmanto, et al. (2015: 5), the promotion media design is essential for the Madakaripura Waterfall Object to increase brand awareness. The design of promotion media required Madakaripura Waterfall includes brochures, magazine ads, posters, pamphlets, billboards, banners, tickets, websites, and videos.

Language is also the dominant delivery medium in introducing the promotion of tourist destinations. Jargon, beautiful sentences, and used promotional language also contributed to the role of tourism promotion. Derived from the language then becomes the story presented in the literature. 
The role of the poet also contribute to the promotion of tourism destinations in Indonesia. Through the story told, the reader is able to describe the atmosphere of the scene of the story and develop a sense of curiosity readers about the location written by the poet.

In 2005 emerging novel called Laskar Pelangi (Rainbow Troops) by Andrea Hirata. English was spoken by the poet of the Pacific Islands region is able to make the reader imagine. Andrea also depicts the beauty of the islands and the atmosphere there. Until finally in 2008 the novel was film, because sales of the best-selling novel. Some literary works created by the poet tells of the natural beauty of Indonesia and is part of the tourist destinations.

Cyber literature, according to Nanang Suryadi (in Faruk, 2001) can open up other possibilities and become an alternative medium in the development of literature. Cyber literature provides ease in accessing rare information so as to spur creativity and the quality of creative work.

Some literary works such as novels written Indonesian poet tells of the background scenery, there are in some tourist destinations. Here is a poet who menceritakan travel background Indonesia, namely: Donny Dhirgantoro, Buya Hamka, Andrea Hirata, Hanum Salsabila, Andika Hendra, Silvarani, and several other poets.

Published in the journal authors Casimeira and Mahagangga (2016: 44), tourism is a matter that has an important role in the development of a country, Therefore, the tourism sector in many developed countries. Moreover, in the era of 2000 to 2018, people were loving world tour.

According to Nature (2006: 179), the promotion is a kind of communication that give explanations and convince potential customers regarding the goods and services in order to gain attention, educate, warn, and convince potential customers. Various ways can be used to promote goods, services, or other travel. Promotions can use the print media, visual media, audio media, to the internet media. This type of promotion that is used to introduce the consumer, especially for tourism in Indonesia have been carried out in various ways. Wonderful Indonesia through the program, attractions in Indonesia is now increasingly known to the public.

This study uses a study of semiotic (semiotics) which is the science of signs. Science assumes that social phenomena or society and culture that is a sign. The study of semiotic systems, conventions allow the signs mean. In literature, the meaning of language is determined by literary convention or adapted to literary convention. Of course, because the material language of literary works that already have the system and convention, it can not be separated entirely from the system of language and meaning. Literature has its own convention in addition to language conventions.

Semiotics is derived from a reality that is present or represented the author to the reader that it contains the potential communicative marked by symbols that have artistic value that are typical of the author. This is because the power of expression continue to grow and thrive author so that it appears a wide variety of writing techniques, symbols of language, language unique style and various types of other expressions.

According Sobur (2007: 84), etymologically the term semiotic derived from the Greek word meaning semeion mark. While the terminology, semiotic can be defined as the study of extensive series of objects, events, all cultures as a sign. According to Barthes in Hoed, social and cultural life is an expression marker (E) mark, while the marker is the content (in French centenu (C), the sign is a relation $(\mathrm{R})$ between $\mathrm{E}$ and $\mathrm{C}$. The connotation is given new meaning in accordance with the user's sign desires, background knowledge, or new conventions that exist in society. the connotation is in terms of "ideology" sign.

Barthes concept clarifies previous research and theory Sasussure and Pierce. The concept of connotation is an example that the painter can describe "love" with paintings of flowers, mothers holding their children and various expressions of similar meaning. Connotation used to describe the socio-cultural situation through the mark by acquiring special significance of community members.

\section{METHODS}

This study uses descriptive qualitative research. By way of literature study literature of the 2000s. The research instrument used is the researchers themselves with the help of analytical tables, to facilitate the classification of literary works written and tourist destinations. Research procedure by: 1) read literary works such as novels, 2) classify literary novel type that tells about the natural beauty 
and tourism in Indonesia, 3) listed in the table analysis, 4) assessing more about which is told in the novel.

According Bungin (2007: 68), descriptive research aims to describe, summarize a variety of conditions or situations, as well as various phenomena of social reality in the community that became the object of research and aims to attract that reality to the surface as a characteristic, character, nature, model, sign, or description of the condition, situation or particular phenomenon.

The focus of this research are manifold literary novel number seven novels are analyzed and linked with existing tourist destinations in Indonesia. This study uses a study in the form of reviews semiotic Roland Barthes divides signs into denotation and connotation.

The primary data used is the seventh novel in the 2000s that tells the story of travel. The novels are novel Laskar Pelangi novel, 99 Cahaya di Langit Eropa, Ada Apa Dengan Cinta (What's With Love), Genduk, Indonesia Berkerabat (Indonesia is related), $5 \mathrm{~cm}$, and Cintaku di Lembata (My Love in Lembata). The secondary data is a literature study done by looking at a variety of references, newsletters, journals, and articles related.

\section{DISCUSSION}

Literary works are studied and associated with travel as a media campaign amounted to 7 novels. The discussion as follows:

\section{A. Laskar Pelangi (Rainbow Troops Novel)}

This novel was published in 2005 by Bentang Pustaka written by Andrea Hirata. Laskar Pelangi (Rainbow Troops) tell about Belitung Muhammadiyah schools and described the atmosphere in the Pacific Islands.

The scenery more beautiful if we climb a small hill on the southwest side of the base. When the evening before, I'm happy to linger sitting alone on a ridge this. Faintly hear the faint sound of children fisher men and women kicked buoy, play ball without goalposts far down there. Their cry was at peace. Around four in the afternoon, the sun will be flushed row of pine trees that grow heavy winds on the steps of the higher hills on the northeast side. Beam obstructed the wind fir pepoh onan huge black triangular shape, exactly where I was sitting. Conversely, on the other hand, plunged contrast ayang light onto the surface of tai shallow pan, so that from a distance I could see the white sand seabed. If I look back, I can see a view of the plains. Thousands sparrow clung tall grass, screaming abysmally, scrambling bed. Next to the savannah that is hundreds of coconut trees and crisscross between the cracks I saw the giant boulders typical pigeon Base. Giant boulders that restrict the banks of the South China Sea and a vast shimmering blue infinity. This entire section showered with sunlight and brackish streams appear until much winding like a silver stream that thawed. Conversely, if I throw a view straight down, toward the formation of air around the stage house earlier, then the sun began to fall just above the orange roofs of leaves nanga 'sticking-nyembul in the shade of the foliage Santigi. Smoke billowed from fires that burn coconut fibers to repel insects sunset. Smoke it, accompanied by the sound of the azan evening, edging penetrate crevices leaf roof, slowly drifting like a ghost village houses, faint creeping branches star that sweet fruit, then swept semilirangin gone, swallowed by the sea. From behind the small windows of houses on stilts scattered below.

The natural beauty that is described in the Laskar Pelangi novel (Rainbow Troops) telling about beauty in Belitung. Has now become a public concern that preparing a vacation time to travel to Belitung. According to Darwin (Media Indonesia.com), since 2012 after the film Laskar Pelangi number of tourists both foreign and local increases. In 2014 returned to foreign tourists increased 2,361 people while local tourists reached 282969 people in total 285329 people.

The presence of Laskar Pelangi (Rainbow Troops) interesting novel to be filmed eventually can become a media campaign to bring in parts of Indonesia with tourists, both local and foreign tourists. Areas in Belitung who is now a sought-after tourist attraction and tourists, namely: Tanjung Tinggi, Andrea Hirata Museum, replica of Laskar Pelangi (Rainbow Troops) in Muhammadiyah Gentong Primary School, and Tanjung Kalayang. Tourist attraction that became the target of tourists to 
vacation. The literary works to be made Museum is a museum of Andrea Hirata in Indonesian literature.

\section{B. 99 Cahaya di Langit Eropa (99 lights in the European sky)}

This novel was written by Salsabiela Rais Hanum and Rangga Almahendra published in 2011. The novel 99 Cahaya di Langit Eropa (99 lights in the European sky) tells the story of a poet in Europe while continuing college. Based on the study of semiotics that these novel uses symbolic language that tells the beauty of Europe. Here's an example of quotation:

We walked past the gate-shaped monument building named Arc de Triomphe du Carrousel. The building of this monument is very similar to the Arc de I'Etoile, monument gate of Paris's iconic Eiffel apart. Monuments Arc de Triomphe du Carrousel which I saw with my own eyes is much smaller than the Arc de I'Etoile, but still looks magnificent. Height of approximately 20 meters and a width of approximately selapangan international size basketball. On top of it there is a statue Quadriga monument, an ancient Greek chariot drawn four life-sized horse. Chariot was ridden woman flanked by two other winged female figures.

Based on the study of semiotics, connotation contained in the written sentence that the poet uses literary language that emphasizes the beauty of the sentence. Because reading the above quote, the reader can imagine about the circumstances described poet. It makes the reader as if they were in that location. Judging from the reviews denotation or actual, that the poet tells of events that are leaders in these locations to describe one by one the circumstances and things that can be seen there. In this case, the poet managed to make the reader as if to see the circumstances described by him. The existence of these stories provide knowledge to the reader about the beauty found in Paris. This makes the reader want to know more detail beauty there,

99 Cahaya di Langit Eropa novel (99 lights in the European sky) invites the reader to see the beauty in continental Europe. The poet described the tourist sites in several areas, namely: Paris, Cordoba, Austria, Vienna city, and several cities in Paris. In this novel tells the story of the poet discover Islam in Europe. Tells the story of the beauty of Islamic civilization which are in Europe. By reading the novel, the reader can imagine about the beauty of the region. This novel made into a film to the big screen. It is part of a media campaign and how people travel to find life there.

\section{C. $5 \mathrm{Cm}$ Novel}

$5 \mathrm{Cm}$ novel published in 2005 by Donny Dirgantoro Grasindo written. This novel tells the story of five friends have the same hobby is adventure. These five friends named Arial, Riani, Zafran, Genta and Lan. This novel depicts the beauty of the top Mahameru and Ranu Kumbolo there. Readers are invited imagination to climb the peak of Mount Semeru or Mahameru. Told about the atmosphere as if the readers see and feel the chill of the top Mahameru.

Here's an excerpt:

Jeeps waiting for climbers who began arriving from various regions. Their appearance is similar all because they have the same goal Mahameru. After that they began to walk, down a rocky road in the village which then turned into a small footpath leading to the ridge Mahameru. The journey continues through the trees at the back Mahameru. From the height of the edge of the slopes of Mount Mahameru, Ranu Kumbolo slowly emerging giants like water droplets falling from the sky and enlarged in front of them. At $02.00 \mathrm{am}$, cold above 3,000 masl. The group stood in front of the tent. Six children were amazed to see Mount Mahameru in the dark of night. After clearing the tent, they started to move past a dark pine forest with makeshift lighting.

Read literature novel $5 \mathrm{Cm}$ was able to bring the readers imagination to Mount Mahameru. Because the novel $5 \mathrm{Cm}$ is the work of best-seller in the bookstore, so that the novel is shown in a movie. After the novel was shown on the big screen, to the attention of the public to watch the film.

After the premiere of the film $5 \mathrm{~cm}$, the number of tourists in TNBTS, particularly the number of climbers of Mount Semeru, increased quite dramatically. As quoted from (m.tempo.co/read/news, head of the TNBTS in Malang, Ayu Dewi Utari, on February 20,2013) said that the climbing spikes occur during the week ranging from 25 December 2012 to 1 January 2013. The number of visitors during the week reached 10,000 visitors. New Years Eve in 2013 alone, there were about 3,000 visitors. In fact, during this TNBTS almost never receive visitors reach 5,000 people in one year. 
Assessed using a semiotic approach, that the novel $5 \mathrm{~cm}$ using a lot of figurative language that makes the reader feel as if the circumstances in the story. This novel form of literary works and the process ekranisasi to the big screen successfully create a society that enjoyed seeing directly Mahameru. This is one way to promote tourism.

\section{Indonesia Berkerabat (Indonesia is related Novel)}

Indonesia Berbakat Novel creation Hendra Andika was published in 2017 by Laksana. This novel tells the story of Bali's natural beauty, ranging from tradition, culture, attractions, and activities there. Telling about seven companions college education. The companions have the same goal of traveling to various places in Indonesia. Activities are not just travel, but social activities, social and cultural study, and are related to the public at that location. The activities they begin in Bali, Indonesia Talented so novel describes the situation in Bali. Here's a sample excerpt about Kintamani and Lake Batur:

Our current cool weather cover up at Kintamani. Very clean oxygen. Minimal pollution, truly an extraordinary pleasure. Natural lakes and mountains become worthy of God's grace to be grateful. Dawn wanted to see some of the fishermen on Lake Batur. By riding a rented motorbike, I and Dawn immediately drove there. "The quality of tilapia and mujairnya how to pack here" asked Dawn to Pak Made Tresna. "Yes, over the years somewhat decreased heck" said Mr. Tresna. "There is little pollution from diesel" Dawn conclusion. "That ship carrying tourists right to use diesel. It also had an impact, "said Mr. Tresna palpable as she headed for the ships carrying tourists.

The novel describes the nature of Bali is said about Mount Batur, Lake Batur, Kintamani, Bali resident, Balinese dance exercise habits using traditional clothing and ceremonial Bali. Talented reading novels Indonesia invites readers to imagine about nature and customs in Bali and also a tourist attraction there. In fact the beauty of the resort island had been known since long ago and a coveted tourist there. The island is the choice of young people who want to feel the romantic feel. Based on the study of semiotics, the symbols set forth by the poet written connotative and denotative. Connotative language form when told of the story of the people of Bali and its culture, while the denotative language is contained in the conversation the young characters in the novel.

\section{E. Ada Apa Dengan Cinta (What's With Love Novel)}

Novel Ada Apa dengan Cinta (What's With Love) is a work that has long and resumed the story. This novel was published in 2016 and written by Silvarani published by Gramedia. The novel was later diakrenisasi into a screenplay and is known for AADC 2. The novel presents a story about a meeting between Love and Rangga after becoming an adult. Because AADC originally in the film directed by Mira ended with Rangga leaving Love. In the novel AADC 2 Silvarani presenting clearly about the state Rangga and his family, and friends love. The novel was later made into a film to continue the story AADC. Recalling the public about the 90s movie Ada Apa Dengan Cinta and poems I have ever known this film.

AADC second story has a background in Yogyakarta. Tells of two lovers are no longer met and ultimately longing. Background used there are several locations that rarely known to the public as Punthuk Setumbung and chicken church.Now, the locations filming AADC 2 be an option package business travel by the makers of travel. Novel AADC 2 describes the situation in Yogyakarta. Explaining the background of Love and Rangga meeting in Punthuk Setumbu, coffee cafe Sally, Ratu Boko temple, Magelang Chicken Church, Parangtritis, Corner Beteng, Tomb Panembahan Senopati, and several other locations.

Background mentioned above are described clearly and the tourist sites in the region of Yogyakarta and surrounding areas. With the story in the novel AADC 2 and then made a movie to make people interested in visiting the tourist attraction. Survey few people who know the story AADC 2, they visited the locations contained in the story. It shows that literary works were read novel finally makes the director interested filmed so that it becomes part of a promotional tour.

\section{F. Cintaku di Lembata (My Love in Lembata Novel)}

Cintaku di Lembata (My Love in Lembata novel) published in 2016 by Gramedia Pustaka Utama by the number of page 192. This novel tells the story of Kayla and Gringgo figures, readers are 
invited to pursue a thousand stairs to watch the weavers in Jontona. Jontona village is also known as a traditional salt-making using palm leaves and sea slugs. Many tourists are interested and come simply see the manufacturing process.

Mountain climbing adventure continues with Ile Lewotolok to the old village Lewohala. Furthermore, the reader is brought to the attraction of traditional whaling in Lamalera, to enjoy the sunset on the Mount of Love, Wolor Pass.

This story is not simply told about the beauty of the island of Lembata, the reader is presented with the love story between Gringgo (Elanda) and Kayla. Gringgo Kupang and Nayla man born of a woman born in Jakarta, feeling the love story separated by space and time. Background place in nature NTT invites the reader to enjoy the natural beauty there. Although have not been to the region, but the reader can feel the beauty of NTT through literary works of this novel.

The theme of the novel tentag love, but the love story that is packed in a travel. The meaning of love contained in the novel is not only a love partner. Instead meanings of love became widespread that love to motherland (homeland), in love with a cultural tradition, and love of one's duties and responsibilities assigned.

Here's an excerpt: Lembata Island reputedly known as Lomblen, which means servant. The nature is largely made up of coastal areas, hills and volcanoes. Resident originally from two ethnic Lamaholot and Kedang. Although the Roman Catholic religion here, Islam, Protestantism, Hinduism and Buddhism. They still had faith in the ancestral and customary to give offerings, is also very strong hold of tradition.

I looked around, the walls of the room white, clean, no poster or photograph attractions.

Redundant let bare walls that could be used to promote a variety of beautiful locations of the

island. "Unfortunately less coordination, while the airport and the harbor entrance merupakam travelers." I complained.

The quote comes from the novel My Love in Lembata. A novel that really tell the beauty, geographical, cultural, social, and customs in NTT. In accordance semiotic studies, this novel use language that clearly describes a denotation of nature there, criticizing the state of the region. Seen in excerpt: ... is it possible to grow tourism in this daeran? Many streets that have not neat, home stay yet have standardization, sanitary and privacy. Many that must be addressed. What's in regional initiatives without the full support of the central government and the wider community? Speech sounds sad tourism representatives in the ears.

\section{G. Genduk Novel}

Genduk novel is a work of poet Sundari Madjuki published by Gramedia Pustaka Utama in 2017. This novel tells the story of eleven year-old girl who lives in the village of peak Sindoro Tomonggongs.

This story uses Sindoro background in the 1970s, about the tobacco farmers have started to be processed and entered in the world's top quality cigarette suppliers.

Here is an example of a novel excerpt Genduk: Journey continues. I see towards rear, Sindoro seem to stand strong. My village look like white spots. ... I surched road to decline, which originally was rocky road is now asphalt. A new lifetime this time I step on the asphalt. Sapto once said if we get to the asphalt streets, will sign up to the city Parakan. Getting down, I have encountered many homes. Then there is the large field and signpost reads "Village Hall", again next to no signpost reads "Primary School". This time the Colt passing vehicles, trucks, and buggy. I was amazed with the number of carriage lined up neatly.

Novel Genduk can be used as promotional media tours to see the beauty Sindoro in Chief of the district. Appropriate assessment of the novel dominant semiotics that uses language connotation, because of the figurative language and some poems written by poets. With the literature, the reader can imagine the state of the region told. Causing a sense of reader's curiosity about the area significantly.

\section{CONCLUSIONS}

After analyzing seven novels about travel. It can be concluded that all studied novel tells about the beauty of travel. Calculated as a percentage of that $80 \%$ of the background story with the natural 
beauty of the location of the story. These novels the theme of love, friendship, religious, and cultural. However, a clear description of the beauty of nature in every story, namely: Sindoro, Islamic civilization in Europe, Belitung, Yogyakarta, NTT, Mount Mahameru, and Bali. These locations, is now the target of the tourists to see the beauty in person.

Can be inferred based on the types of tours according to Asmayanti (2010: 82), based on the following table:

TABLE I. CLASSIFICATION OF TOURISM TYPE

\begin{tabular}{|c|c|c|c|c|c|c|c|c|c|}
\hline \multirow{2}{*}{ No } & \multirow{2}{*}{ Novel } & \multicolumn{7}{|c|}{ Tourism Type } & \multirow{3}{*}{$\begin{array}{l}\text { Description } \\
\text { The beuty of } \\
\text { Belitung and } \\
\text { Muhammadiya } \\
\text { h school }\end{array}$} \\
\hline & & Sport & Culinary & Religious & Argo & Cave & Ecology & Shopping & \\
\hline 1. & $\begin{array}{ll}\text { Laskar } & \text { Pelangi } \\
\text { (Rainbow } & \text { Troops } \\
\text { Nove1) } & \end{array}$ & & & & $\checkmark$ & & & & \\
\hline 2. & $\begin{array}{l}99 \text { Cahaya di } \\
\text { Langit Eropa } 99 \\
\text { lights in the } \\
\text { European } \\
\text { Novel) }\end{array}$ & & & $\sqrt{ }$ & $\sqrt{ }$ & & & & $\begin{array}{l}\text { Islamic } \\
\text { eivilization }\end{array}$ \\
\hline 3. & $5 \mathrm{Cm}$ Novel & & & & $\sqrt{ }$ & & & & $\begin{array}{l}\text { The beauty of } \\
\text { Mount } \\
\text { Mahameru }\end{array}$ \\
\hline 4. & $\begin{array}{l}\text { Indonesia } \\
\text { Berkerabat } \\
\text { (Indonesia } \\
\text { related Nove1) }\end{array}$ & & $\sqrt{ }$ & $\sqrt{ }$ & $\sqrt{ }$ & & & & $\begin{array}{l}\text { The beauty of } \\
\text { Bali }\end{array}$ \\
\hline 5. & $\begin{array}{l}\text { Ada Apa Dengan } \\
\text { Cintar What's } \\
\text { With Love Novel) }\end{array}$ & & & & $\sqrt{ }$ & & & & $\begin{array}{l}\text { The beauty of } \\
\text { Yogya }\end{array}$ \\
\hline 6. & $\begin{array}{l}\text { My Love in } \\
\text { Lembata }\end{array}$ & & & & $\sqrt{ }$ & & $\sqrt{ }$ & & $\begin{array}{l}\text { The beauty of } \\
\text { Lembata Island } \\
\text { NTI }\end{array}$ \\
\hline 7. & Genduk Nove1 & & & & $\sqrt{ }$ & & & & $\begin{array}{l}\text { The beauty of } \\
\text { Mount } \\
\text { Sindoro }\end{array}$ \\
\hline
\end{tabular}

Of the seven novels analyzed, according to the classification tables of the more dominant tourism types tell about agro tourism or natural beauty.

\section{REFERENCES}

Alex Sobur. (2001). Text Analysis Media, Bandung: Youth Rosdakarya.

Ismayanti. (2010). Pengantar Pariwisata. Jakarta: PT Gramedia Widisarana Indonesia.

Casimeira, Azita Yeja and I Gst Agung Oka Mahagangga. (2016). Jurnal Destinasi Pariwisata:

Strategi Pengembangan Bumi Sakti Alam Kerinci Kabupaten Provinsi Jambi. Vol 4. 2. pp 44-48.

Dhirgantoro, Dhonny. (2005). 5 Cm. Yogyakarta: PT Grasindo.

Faruk, H. (2001). Cybersastra: Penjelajahan Awal terhadap Sastra di Internet. Beyond Imagination-

Sastra Mutakhir dan Ideologi , 215-263.

Hendra, Andika. (2017). Indonesia Berbakat. Yogyakarta: Lieu.

Hirata, Andrea. (2005). Laskar Pelangi. Yogyakarta: Landscape Reader.

Ismayanti. (2010). Pengantar Pariwisata. Jakarta: PT Gramedia Widisarana Indonesia.

Mardjuki, Sundari. (2016). Genduk. Jakarta: PT. Gramedia Pustaka Utama.

Narulita, Sari. (2016). Cintaku di Lembata. Jakarta: PT Gramedia Pustaka Utama.

Rais Hanum Salsabiela and Rangga Halmahendra. (2011). 99 Cahaya di Langit Eropa. Cet. 2. Jakarta: PT Gramedia Pustaka Utama.

Silvarani. (2016). Ada Apa Denan Cinta. Jakarta: PT Gramedia Pustaka Utama.

Roland Barthes, Wening Udasmoro (Ed). (2007). Perulangan semiologi. Yogyakarta: Student Library.

Priyatmanto, Baharudin Adam. (2015). Perancangan Media Promosi Objek Wisata Air Terjun Madakaripura Guna Meningkatkan Brand Awareness. Jurnal Desain Komunikasi Visual. Vol.4, No.1, Art Nouveau.

Purnomo, Abdi. (2013).https://gaya.tempo.co/read/463203/gara-gara-5-cm-pendaki-ke-semerumelonjak-drastis, downloadable January 18, 2018. 